\title{
Semantic and syntactic transfer of fitness landscape models to the analysis of collective and public decision making processes
}

\author{
Peter Marks \& Lasse Gerrits
}

Promotie: Erasmus Universiteit Rotterdam, 13 december 2018

Promotoren: prof. dr. Sergey Gavrilets (University of Tennessee) en prof. dr. ing. Geert R. Teisman (Erasmus Universiteit Rotterdam)

\section{Waar gaat het proefschrift over?}

Collectieve besluitvorming heeft een evolutionair karakter: alternatieve keuzemogelijkheden bieden zich aan en verdwijnen weer, waarbij actoren hun strategieën richten op die opties die de grootste overwinningskans lijken te bieden. Modellen om dat evolutionaire karakter om te zetten in causale uitspraken over de relaties tussen strategie aan de ene kant, en variatie, selectie en retentie van keuze-alternatieven aan de andere kant, zijn schaars. Dit gat vullen we op door een model uit de biologie - het zogeheten fitness landscape-model - te vertalen naar bestuurskundige vraagstukken. Een open-source analytische tool (un-code.org) is onderdeel van het proefschrift.

Wat waren de belangrijkste wetenschappelijke conclusies?

Met een aantal aanpassingen kunnen fitness landscapes de evolutie van collectieve besluitvorming structuren, analyseren en visualiseren. Verschillende besluitvormingsprocessen uit binnen- en buitenland zijn met dit model geanalyseerd en gevisualiseerd. In de visualisaties wordt zichtbaar hoe actoren zich bewegen ten opzichte van elkaar gedurende het besluitvormingsproces. Op basis van de analyse en visualisatie hebben we drie actor-archetypes en drie interactiearchetypes in collectieve besluitvorming geïdentificeerd. De actor-archetypes zijn: 'de boei' (een machtige actor die zelf overlevingskansen kan vormen en anderen naar zich toe kan trekken), 'de springer' (een pragmatische actor die zijn voorkeuren en strategie aanpast al naar gelang de overlevingskansen die hij ziet), en 'de inflexibele' (een actor die aan zijn eigen voorkeuren blijft vasthouden, ongeacht de overlevingskansen). De gecombineerde interacties van individuele actoren produceren een zichzelf voortstuwende dynamiek die de verdere evolutie van het collectieve besluitvormingsproces aandrijft. De drie interactie-archetypes zijn: 'force to fit', (actoren proberen patstellingen te doorbreken door middel van 
nieuwe allianties), 'self-organized entrapment' (betreft onvrijwillige groepsvorming als gevolg van wijzigingen in de probleem- en oplossingsdefinities), en 'diversity breeds diversity' (waarbij een relatie wordt gelegd tussen de diversiteit van actoren en de inhoudelijke diversiteit van probleem- en oplossingsdefinities).

\section{Wat kan de praktijk ermee?}

Met het model kunnen de archetypes, en elk andere situatie en strategie in collectieve besluitvorming, worden gelinkt aan de overwinningskansen. Zo zien we dat de boei altijd wel succes kan boeken, en dat de pragmatische springer net zo vaak succes boekt als verliest - pragmatisme levert blijkbaar niet zo veel op. Ook interacties kunnen worden gekoppeld aan succes via complexe dynamiek. 'Self-organized entrapment', bijvoorbeeld, is een vrijwillig gecreëerde situatie die uiteindelijk leidt tot een situatie waar niet uit valt te ontsnappen, ook al levert het veel verliezers op. Het fitness landscape is geen management-tool, maar als analytisch model biedt het zeer goede mogelijkheden om de evolutie in collectieve besluitvorming te structureren, te analyseren en te visualiseren. 